\author{
JURNAL EINSTEIN \\ Jurnal Hasil Penelitian Bindang Fisika \\ Available online http://jurnal.unimed.ac.id/2012/index.php/einsten \\ e-issn: $2407-747 x$, p-issn $2338-1981$
}

\title{
PENGARUH PENAMBAHAN ABU SEKAM PADI SEBAGAI CAMPURAN TERHADAP KEKUATAN BATU BATA
}

\author{
Deslina Zebua, K. Sinulingga \\ Jurusan Fisika, Fakultas Matematika dan Ilmu Pengetahuan Alam, Universitas Negeri Medan, \\ Indonesia \\ deslinazebua@gmail.com
}

Diterima April 2018; Disetujui Mei 2018; Dipublikasikan Juni 2018

\begin{abstract}
ABSTRAK
Penelitian ini bertujuan untuk mengetahui pengaruh dan komposisi terbaik batubata menggunakan abu sekam padi dengan tanah liat terhadap kuat tekan, daya serap air, massa jenis batu bata serta mengetahui struktrur kristal dan fase-fase pengisi pada batu bata. Metode penelitian ini dilakukan dengan menambahkan abu sekam padi $(0 \%, 2 \%, 4 \%, 6 \%, 8 \%)$ dengan tanah liat campuran yang homogen. Penelitian ini dilakukan pencetakan, pengeringan alami selama 14 hari, pembakaran secara tradisional selama $3 \times 24$ jam, dan pendinginan batu bata selama 3 x 24 jam. Berdasarkan standarisasi SII-0021-1978 batu bata merah kuat tekan batu bata penambahan abu sekam padi $2 \%, 4 \%$, dan $6 \%$ mendekati standar mutu kelas 50 sebesar $5.0 \mathrm{MPa}$ dibandingkan tanpa menggunakan abu sekam padi. Penambahan abu sekam padi sebanyak $8 \%$ ternyata menunjukkan daya serap air lebih tinggi dengan nilai section rate yang diijinkan 20 $\mathrm{gr} / \mathrm{dm} 2 /$ menit di bandingkan batu bata dengan abu sekam padi $0 \%, 2 \%, 4 \%$, dan $6 \%$ dengan lama perendaman selama 6 menit. Dari data pengujian massa jenis batu bata dengan menambahkan abu sekam padi pada tanah liat menunjukkan bahwa semakin banyaknya campuran abu sekam padi maka semakin menurunnya massa jenis batu bata. Hasil analisis X-Ray Difraction penambahan $2 \%$ abu sekam padi atau tanpa menggunakan abu sekam padi pada tanah liat memiliki fase dominan SiO2 (Quartz) dengan stuktur Kristal trigonal (hexagonal axes).
\end{abstract}

Kata Kunci : Batu bata, Abu Sekam Padi, Massa Jenis, Daya Serap Air, Kuat Tekan, X-Ray Difraction.

\section{PENDAHULUAN}

Batu bata merupakan bahan bangunan yang telah lama dikenal dan dipakai oleh masyarakat baik dipedesaan maupun diperkotaan yang berfungsi untuk bahan bangunan konstruksi. Hal ini dapat dilihat dari banyaknya pabrik batu bata yang dibangun masyarakat untuk memproduksi batu bata. Penggunaan batu bata banyak digunakan seperti dinding pada bangunan perumahan, bangunan gedung, pagar, saluran dan pondasi. Batu bata umumnya dalam konstruksi bangunan memiliki fungsi sebagai bahan non-struktural, disamping berfungsi struktural. Sebagai fungsi struktural, batu bata dipakai sebagai penyangga atau pemikul beban yang ada diatasnya seperti pada konstruksi rumah sederhana dan pondasi. Sedangkan pada bangunan konstruksi tingkat tinggi/gedung, batu bata berfungsi sebagai non-struktural yang dimanfaatkan untuk dinding pembatas dan estetika tanpa memikul beban yang ada diatasnya. 
Suatu unsur bangunan, yang diperuntukkan pembuatan konstruksi bangunan dan yang dibuat dari tanah dengan atau tanpa campuran bahan-bahan lain, dibakar cukup tinggi, hingga tidak dapat hancur lagi, bila direndam air (Yayasan Dana Normalisasi Indonesia, 1978).

Oleh karena itu, kebutuhan terhadap batu bata dapat terpenuhi dengan menyediakan batu bata yang memenuhi persyaratan teknis, mudah didapat dan harga yang murah sehingga dapat dijangkau oleh masyarakat. Adapun kualitas batu bata yang tersedia kebanyakan mudah retak, hancur, permukaan yang tidak rata dan sudut yang tidak siku akibat kurangnya kualitas batu bata yang dihasilkan. Maka perlu peningkatan produksi yang dihasilkan, dengan meningkatnya kualitas bahan material sendiri (material dasar lempung atau tanah liat) atau dengan mencampurkan bahan-bahan yang bersifat pozzolan seperti abu sekam padi (rice husk ash/RHA) kedalam bahan dasar pembuat batu bata.

Tanah liat merupakan bahan dasar dalam pembuatan batu bata yang memiliki sifat plastis dan susut kering. Sifat plastis pada tanah liat sangat penting untuk mempermudah dalam proses awal pembuatan batu bata. Apabila tanah liat yang dipakai terlalu plastis, maka akan mengakibatkan batu bata yang dibentuk mempengaruhi kekuatan, dan hasil pembakaran batu bata yang sudah jadi (Handayani, 2010) .

Lempung atau tanah liat terdiri dari silikon oksida ( $\mathrm{SiO} 2)$, aluminium oksida (Al2O3), besi oksida(Fe2O3), kapur ( $\mathrm{CaO})$, magnesium oksida ( $\mathrm{MgO})$ dan senyawa kimia lainnya, sedangkan pasir terbentuk dari silikon oksida (SiO2). Oksida-oksida lempung ini tersusun dalam bentuk mineral-mineral lempung seperti kaolinit, illit, dan montmorillonit serta akan memberikan sifat plastis dan kohesif bila ditambahkan air serta memberikan kekerasan dan kekuatan pada hasil setelah pembakaran (Suseno, 2012).

Limbah sering diartikan sebagai bahan buangan/bahan sisa dari proses pengolahan hasil pertanian. Proses penghancuran limbah secara alami berlangsung lambat, sehingga limbah tidak saja mengganggu lingkungan sekitarnya tetapi juga mengganggu kesehatan manusia. Pada setiap penggilingan padi akan selalu kita lihat tumpukan bahkan gunungan abu sekam yang semakin lama semakin tinggi. Saat ini pemanfaatan Abu Sekam Padi tersebut masih sangat sedikit, sehingga abu sekam tetap menjadi bahan limbah yang mengganggu lingkungan. Sekam padi selama ini masih merupakan salah satu produk sampingan dari proses penggilingan padi yang hanya menjadi limbah yang belum dimanfaatkan secara optimal. Sekam padi lebih sering hanya digunakan sebagai bahan pembakar atau dibuang begitu saja (Mujiyanti, 2010).

Sekam padi adalah kulit yang membungkus butiran beras, dimana kulit padi akan terpisah dan menjadi limbah atau buangan. Jika sekam padi dibakar akan menghasilkan abu sekam padi. Secara tradisional, abu sekam padi digunakan sebagai bahan pencuci alat-alat dapur dan bahan bakar. Penggilingan padi selalu menghasilkan kulit gabah/ sekam padi yang cukup banyak yang akan menjadi material sisa. Ketika bulir padi digiling, $78 \%$ dari beratnya akan menjadi beras dan akan menghasilkan 22\% berat kulit sekam. Kulit ini dapat digunakan sebagai bahan bakar dalam proses produksi. Kulit sekam terdiri $75 \%$ bahan midah terbakar dan $25 \%$ berat akan berubah menjadi abu. Abu ini dikenal sebagai Rice Husk Ask (RHA) yang memilki kandungan sillika reaktif sekitar 85\% 90\%. Dalam setiap $1000 \mathrm{~kg}$ padi yang digiling akan dihasilkan $220 \mathrm{~kg}$ (22\%) kulit sekam. Jika kulit sekam itu dibakar pada tungku pembakar, akan dihasilkan sekitar $55 \mathrm{~kg}$ (25\%) RHA. Sekitar $20 \%$ dari berat padi adalah sekam padi, dan bervariasi dari 13 sampai29\% dari komposisi sekam adalah abu sekam yang selalu dihasilkan setiap kali sekam dibakar.

Abu Sekam Padi merupakan hasil dari pembakaran sekam padi. Abu Sekam Padi merupakan salah satu bahan yang potensial digunakan karena produksi yang tinggi dan penyebaran yang luas. Jumlah produksi padi di Indonesia dari tahun 2009-2013, tahun 2013 jumlah total terbesar pada tahun 2013 sebanyak 71.291.494 ton, tahun 2009 sebanyak 64.398 .890 ton, tahun 2010 sebanyak 66.469.394, tahun 2011 sebanyak 65.756.904, tahun 2012 sebanyak 69.056.126 (BPS Indonesia, 2014).

Abu Sekam Padi yang dihasilkan dari pembakaran sekam padi pada suhu 400o- 500o C 
akan menghasilkan silika amorphous dan pada suhu lebih besar 1.000 o C akan menjadi silika kristalin (Bakri,2009). Abu ini dikenal sebagai Rice Husk Ash (RHA) memiliki kandungan silika (SiO2) sekitar 94- 96 \% (Kusuma, 2013). Secara umum Abu Sekam Padi memiliki sifat sebagai pengikat dan pengisi pori-pori apabila dicampur dengan bahan lain. Sehingga Abu Sekam Padi dapat digunakan sebagai bahan perekat dalam pembuatan batu bata.

Komposisi campuran Abu Sekam Padi dalam batu bata yang tepat diperlukan untuk memperoleh kekuatan batu bata yang maksimal ini. Penelitian ini diharapkan dapat :

1. Menjadikan Abu Sekam Padi sebagai bahan pengganti sebagian tanah liat yang digunakan sebagai campuran batu bata.

2. Diperoleh nilai komposisi konsentrasi Abu Sekam Padi pada campuran batu bata yang memiliki kekuatan batu bata terbaik.

3. Mencari jumlah Abu Sekam Padi yang optimum untuk digunakan, sehingga dihasilkan batu bata dengan kualitas yang baik.

\section{METODE PENLITIAN}

Pada Proses penelitian pembuatan sampel dilakukan di Pabrik pembuatan Batu bata Pagar Merbau, Pengujian kekuatan tekan, massa jenis, dan daya serap air dilakukan di Laboratorium Beton Politeknik Negeri Medan, dan analisis X- Ray Difraction di Laboratorium Fisika Unimed pada bulan Januari - Maret 2015.Benda uji yang digunakan dengan ukuran 23 $\mathrm{cm} \times 11 \mathrm{~cm}$ x $5.5 \mathrm{~cm}$, masing-masing divariasikan dengan campuran abu sekam padi pada tanah liat $0 \%, 2 \%, 4 \%, 6 \%, 8 \%$ dengan pembakaran dengan tungku.

Metode yang digunakan pada penelitian ini adalah kajian eksperimental.Secara umum urutan tahapan penelitian ini meliputi :

1. Penyediaan bahan baku batu bata

2. Pemeriksaan bahan

3. Perencanaan campuran batu bata

4. Pembuatan benda uji

5. Pembakaran benda uji

6. Pendinginan benda uji

7. Pengujian batu bata.

Bahan yang digunakan dalam penelitian ini terdiri dari tanah liat/lempung berasal dari daerah Galang, Kabupaten Deli Serdang, dan Abu Sekam Padi berasal dari daerah Binjai.

\section{Pengujian Kuat Tekan}

Batu bata yang sudah dipotong pada sisi panjang menjadi dua bagian yang sama besar. Sebelum melakukan pengujian, sampel diratakan permukaannya agar plat tekan mesin uji betulbetul menempel dengan rata pada seluruh permukaan benda uji, kemudian sampel diukur kembali dimensi panjang dan lebar sehingga diketahui luas penampang yang tertekan oleh mesin uji.

\section{Pengujian Massa Jenis}

Mengetahui massa jenis batu bata dengan penambahan abu sekam padi.

\section{Pengujian Daya Serap Air}

Batu bata yang sudah dioven yang suhu konstan $(110 \pm 5)$ o C sehingga massanya tetap $(A)$. Kemudian batu bata dimasukkan kedalam air dan bidang bawah permukaan batu bata harus bersamaan menyentuh air selama 6 menit. Setelah itu diangkat dengan posisi batu bata vertical, dilap permukaan dengan kain karena kelebihan air. Kemudian batu bata ditimbang dengan neraca (B)gr.

Analisis X-Ray Difraction

Teknik ini digunakan untuk mengidentifikasi fasa kristalin dalam material dengan cara menentukan parameter struktur kisi serta untuk mendapatkan ukuran partikel. Karakteristik X-Ray Difractometry (XRD), yang digunakan dalam temperature ruang dengan menggunakan alat Shimadzu XRD 600 X-Ray diffractometer $(40 \mathrm{kV}, \quad 30 \mathrm{~mA})$, dengan menggunakan nikel untuk menyaring radiasi Cuk $\alpha$ dimana laju scanning yang digunakan adalah dari $0,01 \%$ CPS pada range $2 \theta=5^{\circ}-60^{\circ}$.

\section{HASIL DAN PEMBAHASAN}

Batu bata yang dibuat dengan campuran tanah liat/ lempung, abu sekam padi dan air dilakukan proses pencetakan, pengeringan secara alami selama 14 hari, pembakaran selama 3 x 24 jam, pendinginan 3x24 jam, kemudian dilakukan pengujian massa jenis, daya serap air, kuat tekan dan analisis X-Ray Difraction. Kekuatan batu bata ternyata sangat berpengaruh terhadap komposisi bahan baku penyusun dan proses pembuatannya. 
Hasil pengujian pengaruh penambahan abu sekam padi sebagai campuran terhadap kekuatan batu bata dengan variasi campuran A1 (100:0)\%, A2 (98:2)\%, A3(96:4)\%, A4(94:6)\%, A5 $(92: 8) \%$.

Tabel 4.1. Data hasil pengujian massa jenis, daya serap air, dan kuat tekan batu bata.

\begin{tabular}{|c|c|c|c|c|}
\hline \multicolumn{2}{|c|}{$\begin{array}{c}\text { Variasi } \\
\text { campuran } \\
(\%)\end{array}$} & \multirow{2}{*}{$\begin{array}{c}\text { Massa } \\
\text { Jenis } \\
\text { rata- } \\
\bar{\rho}_{\bar{\rho}} \\
\operatorname{rata}\left({ }^{2}\right) \\
\left(\mathrm{g} / \mathrm{cm}^{3}\right)\end{array}$} & \multirow{2}{*}{$\begin{array}{c}\text { daya } \\
\text { serap } \\
\text { air rata- } \\
\text { rata } \\
(\overline{W A}) \\
\left(\mathrm{gr} / \mathrm{dm}^{2} /\right. \\
\text { menit })\end{array}$} & \multirow{2}{*}{$\begin{array}{c}\text { Kuat } \\
\text { Tekan } \\
\text { rata- } \\
\text { rata } \\
(\bar{P}) \\
(\mathrm{MPa})\end{array}$} \\
\hline $\begin{array}{c}\text { Tana } \\
\text { h liat/ } \\
\text { Lemp } \\
\text { ung }\end{array}$ & $\begin{array}{c}\text { Abu } \\
\text { seka } \\
\mathrm{m} \\
\text { padi }\end{array}$ & & & \\
\hline 100 & 0 & 1.54 & 10.24 & 2.51 \\
\hline 98 & 2 & 1.52 & 11.84 & 3.3 \\
\hline 96 & 4 & 1.51 & 14.66 & 3.1 \\
\hline 94 & 6 & 1.4 & 18.42 & 3.04 \\
\hline 92 & 8 & 1.38 & 20.32 & 2.85 \\
\hline
\end{tabular}

Pengujian sifat fisis dan mekanik batubata dilakukan setelah pendinginan. Dari hasil pengujian batu bata yang menggunakan $100 \%$ tanah liat dan $0 \%$ abu sekam padi diperoleh massa jenis rata-rata $1.54 \mathrm{~g} / \mathrm{cm}^{3}$, daya serap air rata-rata $10.24 \mathrm{gr} / \mathrm{dm}^{2} /$ menit, dan kuat tekan rata-rata $2.51 \mathrm{MPa}$. Untuk batu bata yang menggunakan tanah liat $98 \%$ dan abu sekam padi $2 \%$ diperoleh massa jenis rata-rata $1.52 \mathrm{~g} / \mathrm{cm}^{3}$, daya serap air rata-rata $11.84 \mathrm{gr} / \mathrm{dm}^{2} /$ menit, dan kuat tekan rata-ratanya 3.3 $\mathrm{MPa}$. Untuk batu bata yang menggunakan tanah liat $96 \%$ dan abu sekam padi $4 \%$ diperoleh massa jenis rata-rata $1.51 \mathrm{~g} / \mathrm{cm}^{3}$, daya serap air rata-rata 14.66 $\mathrm{gr} / \mathrm{dm}^{2} /$ menit, dan kuat tekan rata-ratanya 3.1 MPa. Untuk batu bata yang menggunakan tanah liat $94 \%$ dan abu sekam padi $6 \%$ diperoleh massa jenis rata-rata $1.4 \mathrm{~g} / \mathrm{cm}^{3}$, daya serap air rata-rata $18.42 \mathrm{gr} / \mathrm{dm}^{2} /$ menit, dan kuat tekan rata-ratanya 3.04 MPa. sedangkan batu bata yang menggunakan tanah liat $98 \%$ dan abu sekam padi diperoleh massa jenis rata-rata $1.38 \mathrm{~g} / \mathrm{cm}^{3}$, daya serap air rata-rata $20.32 \mathrm{gr} / \mathrm{dm}^{2} /$ menit, dan kuat tekan rata-ratanya $2.85 \mathrm{MPa}$. Untuk lebih jelasnya ditampilkan pada grafik dibawah ini.

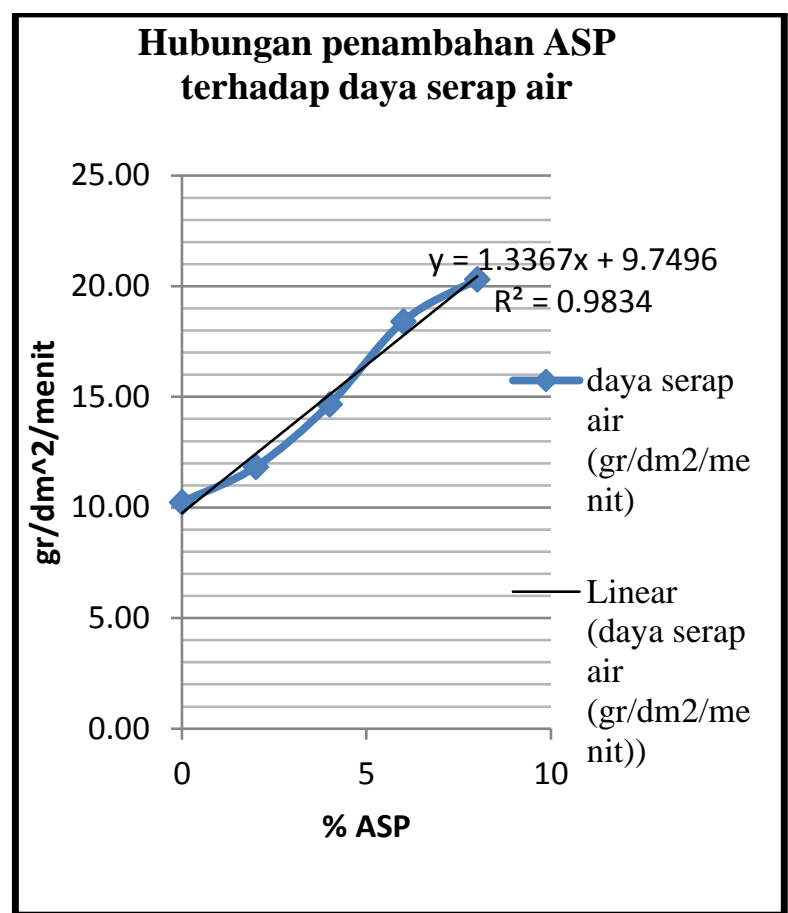

Gambar 4.1.1. Hubungan antara Persentase Volume Abu Sekam padi terhadap Daya Serap Air Batu bata.

Dengan menggunakan program excel diperoleh grafik berbentuk linear dengan persamaan dari hubungan antara persentase volume abu sekam padi terhadap kuat tekan batu bata. Dari grafik tersebut terlihat kecenderungan penambahan abu sekam padi dapat meningkatnya daya serap air batu bata per menit.Hal ini disebabkan porositas abu sekam padi yang sangat tinggi menyebabkan abu sekam

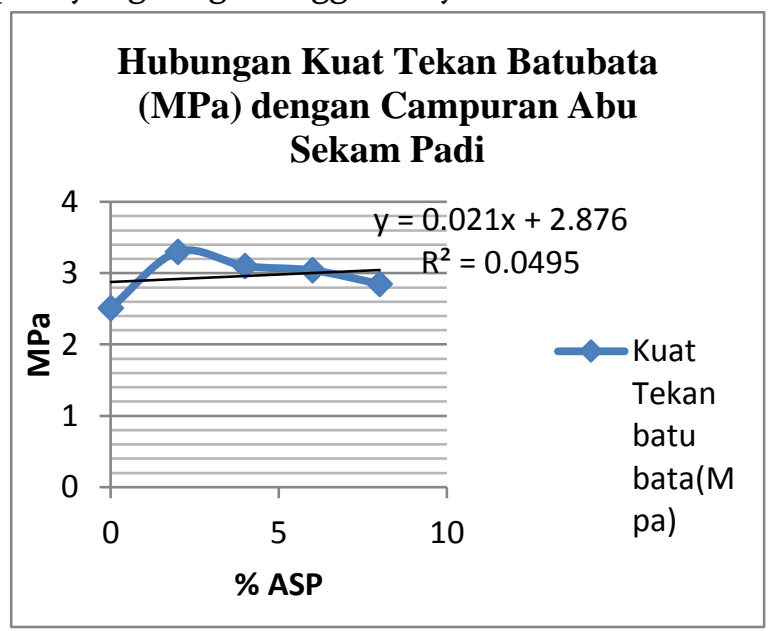

padi dapat menyerap air dalam jumlah banyak (Kaboosi dalam Sinulingga, 2014).

Gambar 4.1.2. Hubungan antara Persentase Volume Abu sekam padi terhadap Kuat Tekan Batu bata . 
Berdasarkan standarisasi SII-0021-1978 batu bata merah (indra, 2012) kuat tekan batu bata penambahan abu sekam padi $2 \%$ mendekati standar mutu kelas 50 sebesar 5.0 Mpa. Sedangkan batu bata dengan 0\%, campuran abu sekam padi berada di standar mutu kelas 25. Dari data yang diperoleh terlihat kecenderungan penggunaan abu sekam padi sebagai campuran pada batu bata akan meningkatkan kekuatan batu bata, akan tetapi semakin banyak menggunakan abu sekam padi dapat menurunkan kekuatan tekan batu bata.

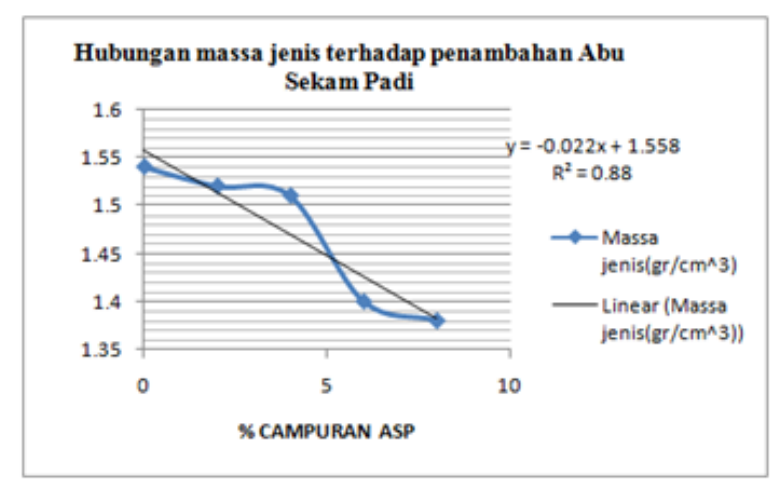

Gambar 4.1.3. Grafik Hubungan antara Massa Jenis terhadap volume abu sekam padi

Dengan menggunakan program excel diperoleh grafik dengan persamaan yaitu $y=-0.022 x+1.558$

dari hubungan antara massa jenis terhadap penambahan abu sekam padi. Penambahan abu sekam padi menyebabkan menurunnya massa batu bata tersebut.

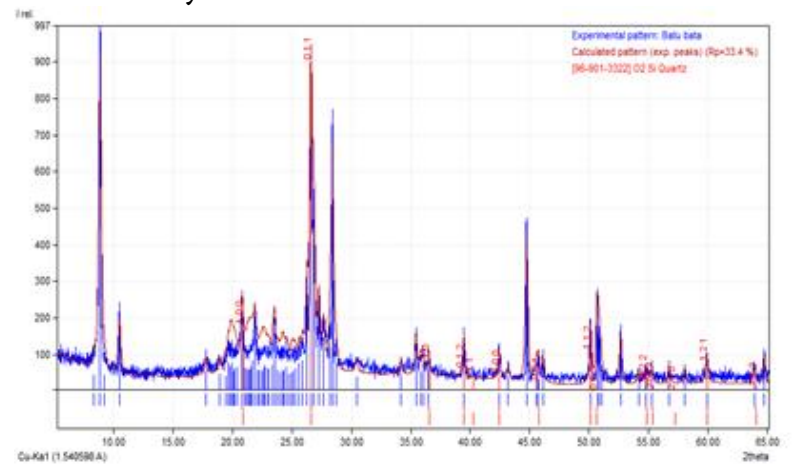

Gambar 4.3. Pencocokan fase batubata normal pada Quartz

Berdasarkan gambar diatas, batu bata yang telah dibakar dan dihaluskan memiliki fase dominan $\mathrm{SiO}_{2}$ (Quartz), dapat dilihat pola batu bata yang dianalisis (warna biru) cocok dengan pola standar untuk fase Quartz (warnah merah) berdasarkan database pola XRD dengan nomor acuan 96-901-2601. Batu bata dengan fase Quartz ini memiliki sistem kristal trigonal (hexagonal axes) dengan nilai $\mathrm{a}=4.9134 \AA \mathrm{c}=5.4051 \AA$, dengan memiliki massa jenis $2.64900 \mathrm{~g} / \mathrm{cm}^{3}$.

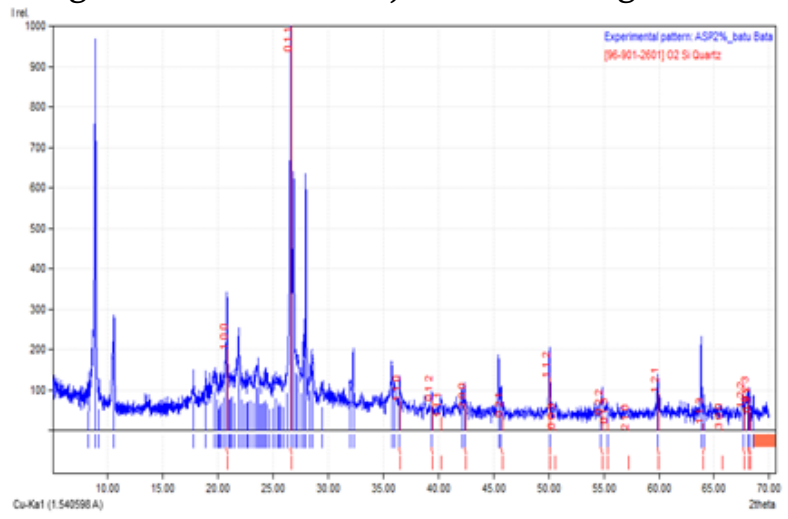

Gambar 4.4. Pencocokan fase batubata dengan $2 \%$ ASP pada Quartz

Berdasarkan gambar diatas, batu bata yang telah dibakar dan dihaluskan memiliki fase dominan $\mathrm{SiO}_{2}$ (Quartz), dapat dilihat pola batu bata yang dianalisis (warna biru) cocok dengan pola standar untuk fase Quartz (warnah merah) berdasarkan database pola XRD dengan nomor acuan 96-901-2601. Batu bata dengan fase Quartz ini memiliki sistem kristal trigonal (hexagonal axes) dengan nilai $\mathrm{a}=4.9140 \AA \mathrm{c}=5.4060 \AA$, dengan memiliki massa jenis $2.64800 \mathrm{~g} / \mathrm{cm}^{3}$.

\section{KESIMPULAN DAN SARAN}

Dari hasil penelitian ini diperoleh kesimpulan:

1. Berdasarkan standarisasi SII-0021-1978 batu bata merah kuat tekan batu bata penambahan abu sekam padi $2 \%, 4 \%$, dan $6 \%$ mendekati standar mutu kelas 50 sebesar 5.0 Mpa.

2. Penambahan abu sekam padi sebanyak 8\% ternyata menunjukkan daya serap air lebih tinggi dengan nilai section rate yang diijinkan $20 \mathrm{gr} / \mathrm{dm} 2 /$ menit di bandingkan batu bata dengan abu sekam padi $0 \%, 2 \%, 4 \%$, dan $6 \%$ dengan lama perendaman selama 6 menit.

3. Dari data pengujian massa jenis batu bata dengan menambahkan abu sekam padi pada tanah liat menunjukkan bahwa semakin banyaknya campuran abu sekam padi maka semakin menurunnya massa jenis batu bata.

4. Hasil analisis X-Ray Difraction penambahan $2 \%$ abu sekam padi atau 
tanpa menggunakan abu sekam padi pada tanah liat memiliki fase dominan $\mathrm{SiO} 2$ (Quartz) dengan stuktur Kristal trigonal (hexagonal axes).

\section{SARAN}

Studi lebih lanjut dengan penambahan campuran yang lain untuk mendapatkan kuat tekan batu bata yang optimum. Memperhatikan lagi proses pencampuran abu sekam padi dengan tanah lempung agar pencampurannya lebih merata. Penelitian batu bata dengan menggunakan tungku pembakar secara tradisional masih sulit untuk mengukur suhu pembakarannya sehingga diharapkan untuk peneliti berikutnya supaya menggunakan tungku listrik sehingga dapat dilakukan penelitian dengan variasi suhu pembakaran. Dengan menggunakan tungku lisrtik juga dapat mengatasi suhu yang tidak stabil dan mengontrol pembakaran dengan baik.

\section{DAFTAR PUSTAKA}

Astuti., A., (1997), Pengetahuan Keramik. Gadjah Mada University Press,

Yogyakarta.

Bakri dan Baharuddin, (2009), Absorpsi Air Komposit Beton Sekam Padi dengan Penambahan Pozzolan Abu Sekam Padi dan Kapur pada Matriks Beton, Jurnal Perennial, 6(2) : 70-78.

Daryanto, (1994),Pengetahuan Alat Dan Bahan,Rineka Cipta, Jakarta.

Elianora, (2010), Variasi tanah lempung. tanah lanau dan pasir sebagai bahan campuran batu bata, Jurnal Teknobiologi, 1(2) 2010 : 34-36 ISSN : 2087-5428.

Handayani, S., (2010), Kualitas Batu Bata Dengan Penambahan Serbuk Gergaji. Jurnal Teknik Sipil \& Perencanaan, No 1 Vol 12. hal 41-50.

Indra, A., (2012), Kuat Tekan (Compression Strength) Komposit Lempung/ Pasir Pada Aplikasi Bata Merah Daerah Payakumbuh Sumbar, Jurnal Teknik Mesin, Vol.1. No.2. April 2012 : 10 -14.

Kusuma, (2013), Pengaruh Penambahan Abu Sekam Padi Terhadap Kekuatan Tekan dan Porositas Genteng Tanah Liat
Kabupaten Pringsewu, Jurnal FEMA, Vol 1. No 1. Januari 2013.

Nawy, E. G., (1990), Beton Bertulang Suatu Pendekatan Dasar, Terjemahan oleh Bambang Suryoatmono, Penerbit PT.Eresco, Bandung.

Nur, O., (2008), Analisa sifat fisis dan mekanis batu bata berdasarkan sumber lokasi dan posisi batu bata dalam proses pembakaran, Jurnal Rekayasa Sipil, Vol4 No.2. Oktober 2008.

Masthura, (2010), Karakterisasi Batu Bata Dengan Campuran Abu Sekam Padi, Skripsi. Universitas Sumatera Utara, Medan.

Putrajaya, R., (2012), Properties of Concrete Containing Rice Husk Ash Under Aggressive Environtments Subjected to Wetting and Drying, Disertasi, Universiti Sains Malaysia, Malaysia.

Sinulingga, K., (2014), Pengaruh Abu Sekam Padi Dan Abu Boiler Kelapa Sawit Sebagai Campuran Terhadap Kekuatan Beton, Disertasi, Universitas Sumatera Utara, Medan.

Siregar, N., (2010), Pemanfaatan Abu Pembakaran Ampas Tebu Dan Tanah Liat Pada Pembuatan Batu Bata, Skripsi, Universitas Sumatera Utara, Medan.

Suseno, (2012), Pengaruh Penggunaan Bottom Ash Sebagai Pengganti Tanah Liat Pada Campuran Bata Terhadap Kuat Tekan Bata, Jurnal Rekayasa Sipil, Vol 6. No.3 - 2012 ISSN 1978-5658.

SK SNI S-04-1989-F, (1989), Ukuran Batu Bata Standar, Standar Nasional Indonesia.

Vlack, V. L., (1994), Ilmu dan Teknologi Bahan, Terjemahan: Sriati Djaprie. Edisi ke-5. PT. Erlangga, Jakarta.

Yayasan Dana Normalisasi Indonesia, (1978), Bata Merah sebagai Bahan Bangunan edisi ke-2, Bandung YDNI, NI-10.

http:// www. Elearning. gunadarma. Bab 7. Bata merah. Dikutip tanggal 29 September 2014. 